\title{
Works Printed by K.K. Merker: the Stone Wall Press, the Windhover Press, and Others
}

\author{
Introduction KA Y A MERT
} Checklists O M BRACK, JR. andK. K. MERKER

lowa City has provided a congenial setting for some of the significant American private presses of the twentieth century. Not the least of these are the Stone Wall Press and the Windhover Press. Both are directed by $\mathrm{K}$. K. Merker, whose involvement in the private press tradition now spans 20 years. The Stone Wall Press, Merker's own private press, was established in 1957 and publishes primarily contemporary American poetry. The Windhover Press was established in 1967 and is sponsored by The University of Iowa. Windhover's publications include literary, historical, and scholarly material.

Kim Merker came to Iowa City in 1956 as a poet and a student in the Writers' Workshop. While at the University he had the opportunity to work with Harry Duncan, who operated the highly regarded Cummington Press and who was then the director of the Typography Laboratory in the School of Journalism. Duncan and Merker collaborated on a number of publications. The Stone Wall Press was established by Merker and Raeburn Miller, a fellow student in the Writers' Workshop who was soon to leave Iowa City in pursuit of an academic career.

Over the past two decades, Merker has published such renowned poets as Ezra Pound and Theodore Roethke as well as younger poets such as W. S. Merwin, Donald Justice, Mark Strand, and Philip Levine. The Stone Wall books have been issued in editions of 200 to 300 copies. They employ fine printing papers, impeccably chosen type designs, nearly flawless hand-composition, meticulous printing executed on hand-presses, and hand-binding. The approach to design exercised in the books is pristine and classical in nature, and color is used with restraint. Theodore Roethke's Sequence, Sometimes 
Metaphysical is a particularly elegant representation of the Stone Wall quality.

The establishment of the Windhover Press in 1967 by The University of Iowa innovatively situated a private press in an academic setting. Windhover is in part a teaching press. Students with interests in bibliography, publishing, or bookmaking are able to work directly with Merker and to participate in the design and execution of the publications. The Windhover bibliography includes translations, poetry by distinguished international writers and little-known or unpublished literature by such historical figures as Thoreau and $F$. Scott Fitzgerald. John Hoole's Journal Narrative Relative to Dr. Johnson's Last Illness, a manuscript of primarily scholarly interest, is representative of the diversity of Windhover's publications. Edition sizes and production methods are similar to those of the Stone Wall Press, and the high standards visible in those books are maintained under Merker's direction.

The two presses occupy a special place in the erratic tradition of the private press. Both have solid editorial programs which emphasize worthy unpublished or otherwise unavailable material. Both issue books which are well designed and meticulously crafted. The combination of meritorious literature and fine bookmaking is uncommon.

Collectively, the items listed in the following bibliography have received every major American award for editorial and graphic excellence. The future promises such distinguished publications as the collected poems of Ernest Hemingway.

The numbering system employed in the bibliograpby is not strictly chronological. Rather, numbers 1-199 are reserved for Stone Wall Press publications, 200-399 for Windhover Press publications, 400-499 for collaborative publications with Harry Duncan's Cummington Press, and 500-599 for collaborative publications with A. D. Moore's Finial Press. The number in parentheses at the end of each entry, however, shows the place of the book in the overall chronological sequence of Kim Merker's book production.

\section{The Stone Wall Press}

1. A BOOK OF KINDS, Poems by Margaret Tongue with illustrations by Constance Merker, 1958. 6\% 3 3\%; 40 pages; 12-point De Roose and 16-point Romanée Capitals, handset; black and blue; 320 copies on Crown and Sceptre; bound in blue cloth boards, blocked in black on spine, by RussellRutter.

2. THE COLLECTED POEMS OF WELDON KEES, Edited by Donald Justice, 1960. $9 \pi_{8}^{\tau} \times 6 \%$; 143 pages; 12-point Romanee and Lutetia Italic, with 16point Romanée and 28-point Romanée Capitals, handset; title page and fly- 
titles in black and red; 200 numbered copies (I-XX on Rives Heavy, bound in full black Oasis goatskin, blocked in gold on spine, blindstamped on front; 1-180 on Rives Light, bound in gray-green paper boards with black leather spine, blocked in gold on spine, blindstamped on front) with bindings by Elizabeth Kner.

3. GARDENING, A Poem by Vern Rutsala, 1960. 97 x 4\%; 4 unnumbered pages (French fold); 12-point Romanée, handset; ornament printed in brown and hand-colored in yellow; 150 numbered copies on Curtis Rag, signed by the author.

4. EXCERPTS FROM DAVID KNUDSEN, Selected by the Author, George P. Elliott, 1960. 6\% x 8\%; 4 unnumbered pages (French fold); 12-point Romanée, handset; black and red; 150 numbered copies on Curtis Rag, signed by the author.

5. FEVER \& CHILLS, A Poem by George P. Elliott, 1961. 9\% x 4\%; 37 pages; 12-point Romanée and Double Augustin Open Capitals, handset; title and initial capital in red; 220 numbered copies on Weimar and Umbria; bound in gray paper boards with dark blue leather spine, blocked in gold on spine, by Elizabeth Kner.

6. THE POEMS OF MEGAN MERKER PRINTED FOR HER GRANDFATHER ON HIS BIRTHDAY OCTOBER 2, 1961. 6\% x 37; 4 unnumbered pages; 16-point Romanée, handset; black and red; 20 copies on Umbria with author's mark (a red fingerprint); bound in green paper wrapper.

7. ON THE EDGE, Poems by Philip Levine, 1963. 9/2 $\times$ 5\%; 63 pages; 14- and 16-point Romanée, handset; red slash on title page; 220 copies on Golden Hind; bound in brown paper boards, with label on spine, by Elizabeth Kner.

8. SEQUENCE, SOMETIMES METAPHYSICAL, Poems by Theodore Roethke, with wood engravings by John Roy, 1963. 10\% x 6\%; 31 unnumbered pages and 12 engravings, each on folded leaf; 16-point Romanée and Double Augustin Open Capitals, handset; 330 numbered copies on Rives Heavy and Mulberry (I-LX signed by the author and the engraver, bound in printed paper boards with red leather spine, blocked in gold on spine; $61-330$ bound in red paper boards, blocked in gold on spine); bindings, with black slip cases, by Elizabeth Kner.

9. SLEEPING WITH ONE EYE OPEN, Poems by Mark Strand, 1964. 8\% x 5\%; 55 pages; 12-point Romanee, handset; fly-titles, containing the number for the three sections, are in red; 225 numbered copies on Curtis Rag; bound in red cloth boards, blocked in gold on spine, by Elizabeth Kner.

10. THE INFINITE ABSENCE, Poems by Miguel Gonzalez-Gerth, with preface by Richmond Lattimore and wood engravings by John Roy, 1964. 5 × 75; 23 pages; 12-point Romanée and Lutetia Italic, handset; 250 numbered copies on Rives Heavy, bound in dark blue paper boards, blocked in gold on spine, by Elizabeth Kner. Printed for the author.

11. POEMS FROM XV LANGUAGES, Translated by members of the Program in Creative Writing at The University of Iowa, 1964. $8 \%$ x 5\%; 28 pages; 12point Romanée and Lutetia Italic; title page in black and red; 2-leaf insert at page 25 in black and red Gaelic script, printed offset; 500 copies on Curtis Rag; 150 copies bound in brown paper boards, printed on front, by Elizabeth Kner; 350 copies bound in brown paper covers, printed on front. The front of both bindings contains an example of contemporary Korean calligraphy by Cho Sung-kyun.

12. IN HONOR OF THE VISIT BY YVES BONNEFOY TO THE WORKSHOPS IN POETRY AND TRANSLATION AT THE UNIVERSITY OF IOWA, 11 December 1964. An Appreciation by Paul Engle with a poem in French (La Chambre) by Bonnefoy with a translation by Peter Clothier. 6r: 15 (folded twice); 6 unnumbered pages; 14-point Romanée, handset; title page in black and red; approximately 250 copies on Fabriano Book. 
13. ALL KINDS OF LOVE, Poems by Norma Lowry with a wood engraving by Fred Becker, 1965. 9\% x 6; 56 pages; 14-point Romanée, handset; title page in black and red; 250 copies on Fabriano Book; bound in blue cloth boards, blocked in gold on spine, by Elizabeth Kner. Privately printed.

14. AMERICAN CHRISTMAS, Edited by Webster Schott and Robert J. Meyers. 1965. $10 \times 6 \%$; 75 pages; 14-point Romanée with 16-point Romané Capitals. handset; black and red; large trade edition; bound in red cloth boards, blocked in gold on spine, blindstamped on front. Printed offset by the publisher, Hallmark Cards, Incorporated.

15. A GEOGRAPHY, Poems by Thom Gunn with a wood engraving by John Roy. 1966. 71/2 4 4\%; 32 pages; 14-point Romanée, handset; black and red, with the engraving in dark green; 220 on Rives Light, signed by the author; bound in red paper covers, printed on front.

16. THINGS WE DREAMT WE DIED FOR, Poems by Marvin Bell, 1966, $8 \times 47 ; 79$ pages; 12-point Romanée and Double Augustin Open Capitals. handset; title and fly-titles enclosed in double rules with center colored by hand in yellow; initials colored by hand in gray; 270 copies on Arches, bound in gray cloth boards, blocked in gold on spine, by Elizabeth Kner.

17. AMERICAN CHRISTMAS (Second Edition), Edited by Webster Schott and Robert J. Meyers, 1967. $10 \times 6 \%$; 96 pages; 14-point Romanée and Double Augustin Open Capitals, handset; large trade edition; bound in red cloth boards, blocked in gold on spine, blindstamped on front. Printed offset by the publisher, Hallmark Cards, Incorporated.

18. NOTES OF WOE, Poems by James Tate, 1968. 7\% $x 5$; 48 pages; 14-point Romanée, handset; black and blue; 230 copies on Hayle; bound in terra cotta paper boards, blocked in gold on front, by Elizabeth Kner.

19. DRAFTS \& FRAGMENTS OF CANTOS CX-CXVII, Poems by Ezra Pound 1968. 12\% x 8\%; 41 pages; 14-point Romanée and 20-point Cancelleresca Bastarda, handset; black and red; 310 numbered copies ( I-200 for New Directions, New York; 201-300 for Faber and Faber, Limited, London; 301-310 for the Stone Wall Press), signed by the author, on Umbria; except for the Stone Wall Press copies, still in sheets, bound in red cloth boards, with label on spine, in gray slip case with label on front, by A. D. Moore.

20. SMALL SONGS, A Sequence of Poems by Vern Rutsala, 1969. 6\% $x$ 4\%; 17 pages; 14-point Romanée Italic, handset; 180 copies on Rives Light; boind in blue paper covers, printed on front.

21. THE MAN AMONG THE SEALS, Poems by Denis Johnson, 1969. 8\% $\times$ 5\%; 56 pages; 12-point Romanée, handset; black and red; 260 copies on Curtis Rag; bound in brown cloth boards, with label on spine, by Russell-Rutter.

22. SIXTEEN POEMS, by Donald Justice, 1970. 111\% $\times 7 ; 31$ unnumbered pages; 14-point Romanée and 28-point Romanée Capitals, handset; 250 copies on Curtis Rag; bound in brown paper covers, printed on front.

23. IN THE HOUSE OF LIGHT: THIRTY AZTEC POEMS, Translated by Peter Everwine, 1970. 9\% x 6\%; 40 pages; 14-point Romanée and 12-point Lutetia Italic, handset; gray-green ornament on title page; 250 copies on Fabriano Book; bound in gray-green cloth boards, blocked in gold on spine, by Elizabeth Kner.

24. LIVING IN IT, Poems by C. G. Hanzlicek, 1971. 9\% $x 5$; 56 unnumbered pages; 12-point Joanna, handset; black and red; 240 copies on Maidstone; bound in brown cloth boards, blocked in gold on spine, by Mary Ellen Chapdu.

25. POIKILOS, Poems by Tom Meyer, 1971. 6\% x 4; 33 unnumbered pages; 14point Spectrum Italic and Double Augustin Open Capitals, handset; 250 copies on Rives Light; bound in black cloth boards, blocked in gold on front with abstract Greek letter $\pi$ by Mary Ellen Chapdu. Each copy has a threecolor, hand-tied macramé bookmark. A joint publication with the Finial Press. 


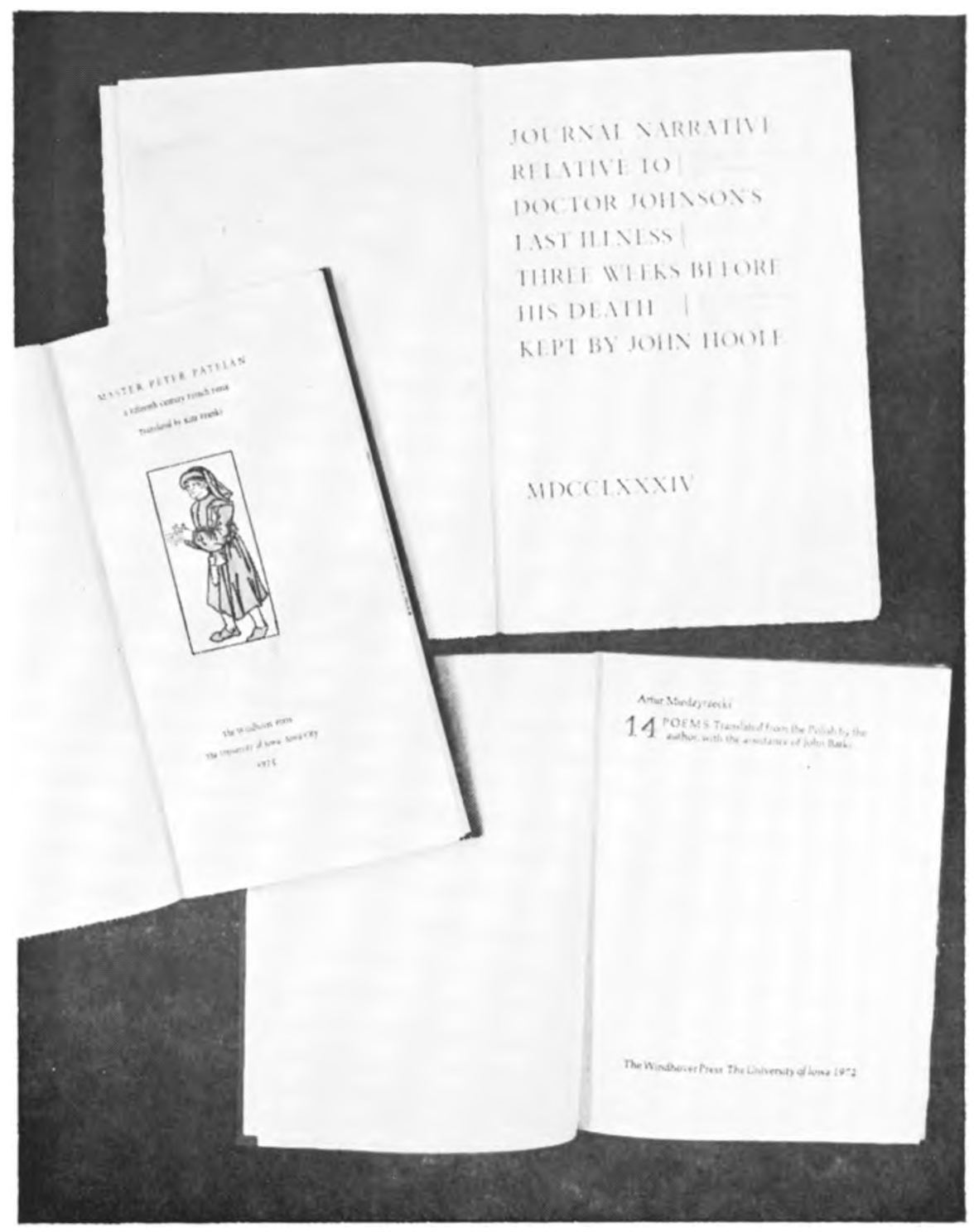

Three books printed at the Windhover Press of The University of Iowa: Master Peter Patelan, a fifteenth-century French farce in a new translation by Kate Franks ( 1975); John Hoole's account of the last three weeks of the life of Samuel Johnson (1972); and 14 Poems by Artur Miedzyrzecki (1972). 


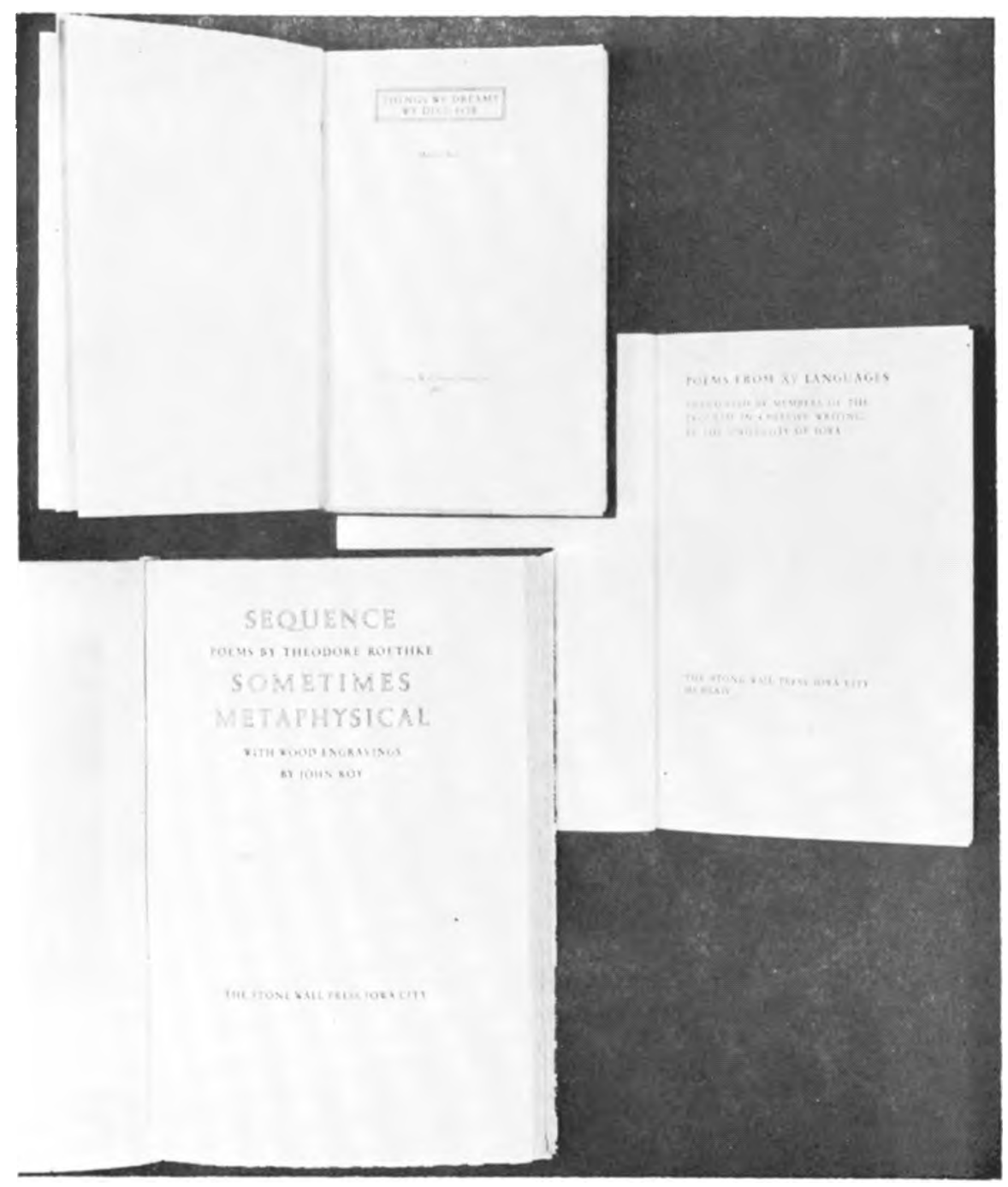

The work of Kim Merker's Stone Wall Press is represented above by Marvin Bell's Things We Dreamt We Died For (1966); Poems from XV Languages (1964); and Theorlore Roethke's Sequence, Sometimes Metaphysical (1963). 
(A. D. Moore, of the Finial Press, provided the manuscript, but was not involved in the production.)

26. SIGNS, A Poem by W. S. Merwin with graphics by A. D. Moore, 1971 . 4\% x 9\%; 39 unnumbered pages; 14-point Spectrum, handset; graphics in yellow, gray lines dividing pages printed offset; 200 copies on Rives Light, signed at the colophon by the author and the illustrator; bound in black cloth boards, silkscreened on front, by Elizabeth Kner.

27. CARGO, Poems by Paul Nelson, 1972. $8 \times 5^{\frac{1}{4}}$; 63 pages; 14-point Emerson, handset; title in stencil-letter, printed blue; 250 copies on Tovil; bound in blue cloth boards, with label on spine, by Howard Zimmon. Printed with Kay Amert and Howard Zimmon; a joint publication with the Seamark Press.

28. THE WICHITA POEMS, by Michael Van Walleghen, with prints by William Kough, 1973. $10 \times 513$; 55 pages; 14- and 16-point Romanee, handset; 250 copies on Rives Light; bound in natural Japanese paper boards, with label on spine, by Mary Ellen Chapdu.

29. THE MAN CLOSING UP, A Translation and an Improvisation by Donald Justice, 1973 (with the French text, L'homme Qui Se Ferme, by Guillevic). $10 \% \times 7{ }^{5} ; 15$ unnumbered pages with the Improvisation on a leaf which folds out, tipped in at the end; 12- and 14-point Bembo, handset; 150 copies on Crown \& Sceptre; bound in gray paper wrappers, printed on front.

30. THE ILIAD OR THE POEM OF FORCE, by Simone Weil, Translated by Mary McCarthy, with a Preface by George P. Elliott, and A Note on Simone Weil, adapted from an article by Candide which was printed with the original Politics edition, 1973. 7\% x 4\%; 53 pages; 10- and 12-point Romanée, handset; 150 copies on Crown \& Sceptre; bound in brown paper boards, with label on spine, by Mary Ellen Chapdu.

31. THE STONE WALL BOOK OF SHORT FICTIONS, Edited by Robert Coover and Kent Dixon, 1973. $10 \times 6 \%$; 77 pages; 14-point Bembo and 24point Bembo Titling Capitals, handset and machineset; black and red; 325 copies on Rives Light; bound in dark blue cloth boards, with label on front, by Mary Ellen Chapdu.

(65)

32. DEPARTURES, by Donald Justice, 1973. $9 \times 6$; 65 pages; 12- and 14-point Emerson, and Double Augustin Open Capitals, handset; black and red; 175 copies numbered and signed by the author of Fabriano Book; bound in natural linen cloth boards, blocked in red and blindstamped on front with label on spine, by Mary Ellen Chapdu. A joint publication with the Penumbra Press. Atheneum Publishers issued a large trade edition, printed offset from this setting.

33. DUES, Poems by Michael Lally, 1975. $8 \times 5 \%$; 14-point Romanée, handset; black and red; 235 copies on Ragston, bound in dark gray cloth boards, with label on spine, by Constance Sayre.

34. FIVE IOWA POEMS, by Robert Sward \& ONE IOWA PRINT, by Michael Nushawg, 1975. $13 \times 10 ; 13$ unnumbered pages; 16-point Romanée and Weiss Titling ampersands; 250 copies on Rives Light; bound in gray paper wrappers, printed on front.

35. THE CHICAGO LANDSCAPES OF ART SINSABAUGH, essays by Henry Holmes Smith and Sherman Paul, with a history of the project by the photographer, 1976. $10 \times 6 \%$; 47 pages; 14- and 16-point Bembo, and 36-point Bembo Titling Capitals, handset; black and red; 300 copies on Rives Heavy; bound in natural cloth over silkscreened boards, with label on spine, by Constance Sayre.

\section{The Windhover Press of The University of Iowa}

200. WINDHOVER :: I LAMENT FOR THE MAKARIS, A Poem by William Dunbar, 1967. $8 \times 5$; 8 unnumbered pages; 14-point Joanna, handset; black 
and red; 100 copies on Rives Light; bound in brown paper wrappers, printed on front. "This pamphlet is the first in a series of ephemera, designed primarily to represent the typefaces of The Windhover Press."

201. THOREAU: TWO FRAGMENTS FROM THE JOURNALS, Edited, with a preface, by Alexander C. Kern, with a wood engraving by John Roy, 1968. $7 / 2 \times 4 \frac{1}{2} ; 16$ unnumbered pages; 12-point Joanna, handset; black and red; 200 copies on Fabriano Book; bound in brown paper boards, blocked in gold on spine, in slip case, by Russell-Rutter.

202. WINDHOVER :: II PERPETUUM MOBILE, A Poem by Sir Thomas Wyatt, 1968. 10\% x 5; 3 unnumbered pages; 14-point Emerson, handset; black and green; approximately 200 copies on Shinsetsu; bound in brown paper wrappers, printed on front.

203. VOLUSPA: THE SONG OF THE SYBIL, Translated by Paul B. Taylor and W. H. Auden, with the Icelandic text edited by Peter H. Salus and Paul B. Taylor, 1968, 97/ $\times 6 \%$; 31 unnumbered pages with the Notes on a leaf which folds out, tipped in at the end; 14-point Bembo, handset; the decorative brackets and frontispiece adapted by Mary Ellen McFadden from early Icelandic representations of Thor's hammer and the initial drawn by Irwin McFadden are printed in blue; 450 copies on Rives Heavy; bound in gray paper boards, blocked in gold and blindstamped with frontispiece on front, by Elizabeth Kner.

204. SALT, Poems by Ya Hsien, translated from the Chinese by the author, 1968. $10 \%$ x 7\%; 24 pages; 14-point Emerson, handset; black and red; 250 copies on Shinsetsu, bound in green paper covers, printed on front.

205. WINDHOVER :: III THREE SONNETS \& ONE DRAWING, Poems by George Starbuck and a drawing by Miguel Conde, 1968. $10 \times 6 \% ; 7$ unnumbered pages; 12-point Palatino, handset; black and red; 220 copies on Rives Light; bound in brown paper wrappers, printed on front.

206. WINDHOVER :: IV AND FOUR WITH BIRDS, Poems by Sherman Paul, 1968. 7\% $1 \frac{13}{2} ; 18$ unnumbered pages; 16-point Bembo, handset; title page in black, red and blindstamping; text in black, blue, and blindstamping; 175 copies on Curtis Rag; bound in brown paper wrappers, printed on front.

207. THE RED UMBRELLA, Poems by Tahereh Saffarzadeh, translated from the Persian by the author, with a copper engraving by Carolyn Anderson (printed on red paper and tipped onto title page), 1969. 9\% x 5\%; 24 pages (folded along fore edge); 12-point Bembo, handset; 320 copies on Shinsetsu; bound in gray paper covers, printed on front, by Carolyn Anderson.

208. REGARDING WAVE, Poems by Gary Snyder, 1969. 87\% 5 5\%; 48 pages; $12-$ point Emerson, handset; 280 numbered copies on Shogun Heavy, signed by the author; bound in burgundy cloth boards, blocked in gold on front (ornament on spine), by Elizabeth Kner.

209. DEARLY BELOVED, A Short Story by F. Scott Fitzgerald, with graphics by Byron Burford, and a note by Matthew J. Bruccoli, 1969. 14 x 10; 11 unnumbered pages; 16-point Bembo, handset; black and gray (graphics in red, green, and gray); 300 numbered copies (1-30 signed by the artist) on Ruysdael Rag; bound in gray-green paper boards with black leather spine, blocked in gold on spine, by Elizabeth Kner.

210. THE FABUl OUS LIFE OF GUILLAUME APOLLINAIRE, A Poem by Gunnar Harding, translated from the Swedish by Gunnar Harding and Sydney Smith, with silkscreen prints by Carolyn Anderson and Michael Nushawg, 1970. 97\% x 6\%; 23 unnumbered pages; 12-point Emerson and Double Augustin Open Capitals, handset; prints in red, yellow, blue, and green; 320 copies on Rives Heavy; 120 copies bound in gray paper boards, blocked in gold on spine, by Mary Ellen Chapdu; 200 copies bound in gray paper covers, printed on spine and front.

211. WINDHOVER :: V THE ILIAD, Book Eight, Lines 553-565, Translated 
by Robert Fitzgerald, 1970. 11 x 8; 3 unnumbered pages (French fold); 14-point Palatino, handset; title page in red and black; 350 copies on Shinsetsu; bound in brown paper wrappers, printed on front.

212. KENNEY'S: TWENTY POEMS FOR A LOST TAVERN, Foreword by William Murray, 1970. 8\% x 51/2; 47 unnumbered pages; 10-point Bembo, handset; 250 copies on Curtis Rag; bound in blue paper boards with black cloth spine, blocked in gold on front, by Elizabeth Kner.

213. HOPSCOTCH, Prints and Text by Carolyn Anderson, 1970. $7 \times 7 ; 20$ unnumbered pages; 16-point Bembo Italic; black, red, and transparent white; seven intaglio prints in yellow, red, blue, and black; 15 numbered copies on Rives BFK; bound in black cloth boards by the author.

214. HUCKLEBERRIES, An Essay by Henry David Thoreau, edited, with an introduction, by Leo Stoller and a preface by Alexander C. Kern, with drawings by Carolyn Anderson, 1970. $10 \times 6 \%$; 52 pages; 12-point Emerson and 28-point Romanée Capitals, handset; 330 copies on Rives Heavy; bound in black cloth boards, blocked in gold on spine, blindstamped on front, in slip case, by Mary Ellen Chapdu. A joint publication with the New York Public Library. (50)

215. THRYMSKVITHA, Translated from the Old Norse by Sidney Berger, final version by Sidney Berger and Anselm Hollo, 1970 (with Old Norse text en face). 9\% x 6\%; 16 pages (French fold); 14-point Bembo, handset; 200 copies on Venezia; bound in terra cotta paper covers, printed on front.

216. PASSION PLAY, A Dramatic Fragment, 1878, by Bernard Shaw, edited by Jerald E. Bringle, 1971. 12\% 8 ; 61 unnumbered pages; 14-point Romanée and 20-point Cancelleresca Bastarda, handset; black, red, gray, and blue; 350 copies (1-25 for the Windhover Press; 251-350 for Bertram Rota, Limited, London) on Umbria; bound in boards covered with specially made pastepapers with linen spine, with label on spine, in linen slip case, by Mary Ellen Chapdu.

(55)

217. 14 POEMS, by Artur Miedzyrzecki, translated from the Polish by the author, with the assistance of John Batki, 1972. 8\% 6 6\%; 24 unnumbered pages (French fold); 12-point and 14-point Palatino and 30-point Augustea Inline Capitals; capitals colored by hand in yellow; 300 copies on Suzuki; bound in yellow paper covers, printed on front.

(56)

218. JOURNAL NARRATIVE RELATIVE TO DR. JOHNSON'S LAST ILLNESS THREE WEEKS BEFORE HIS DEATH KEPT BY JOHN HOOLE, MDCCLXXXIV, Edited by O M Brack, Jr., with frontispiece etching by John Thein, 1972. $10 \times 6{ }^{1}$; 34 pages; 16- and 12-point Bembo and 24-point Bembo Titling Capitals, handset; black and red; 250 copies on Rives Heavy; bound in black cloth boards, blocked in gold on spine, by Elizabeth Kner.

219. HERCULE CHRESTIEN. by Pierre de Ronsard. Translated from the French by F. W. Bornhauser, with the French text en face and an Afterword by Oliver Steele, 1972. 6\% $\times$ 4\%; 39 unnumbered pages; 14- and 12-point Bembo, handset; black and red; 200 copies on Fabriano Book; bound in paper boards with brown cloth spine, blocked in gold on spine, by Mary Ellen Chapdu.

220. TURBINES, Twenty-one Poems by Tomaz Salamun, Translated from the Slovenian by the author, with the assistance of Anselm Hollo and Elliott Anderson, 1973. 8\% x 5\%; 29 pages; 12-point Bembo, handset; black, red, and transparent white; 275 copies on Shogun; bound in black paper covers, printed on front.

221. ELEGY FOR MY FATHER, by Mark Strand, with photosilkscreens by Gretchen Esping, 1973. 9\% $\times$ 8\%; 15 unnumbered pages; 14-point Bembo and 24-point Bembo Titling Capitals, handset and printed by Shari Madsen, Pillar Guri Press; black and red; 150 copies on Shogun; bound in black paper wrappers, printed on front.

222. A CUB TELLS HIS STORY, by John O'Hara, with a preface by Matthew J. Bruccoli, 1974. 8\% x 5; 13 unnumbered pages; 10-point Bembo and 10 and 
12-point Spartan Bold, handset; black and red; 150 copies on Windhover paper; bound in gray paper wrappers, printed on front; a joint publication with Bruccoli Clark.

223. CHARLES OLSON IN CONNECTICUT: LAST LECTURES, as heard by John Cech, Oliver Ford, and Peter Rittner, with a portrait of Olson made from an engraving by Edward Sullivan, 1974. $7 \times 8$; 66 pages; 12-point Bembo, handset; black and red; 220 copies on various papers (Shogun. Suzuki, and Windhover); bound in black cloth boards, with label on spine. by Mary Ellen Chapdu.

224. MASTER PETER PATELAN, a fifteenth century French farce translated by Kate Franks, illustrated with photoengravings of the woodcuts from the original edition, 1975. $10 \times 5 \%$; 96 pages; 14- and 12-point Joanna, handset; 225 copies on Ragston; bound in terra cotta and white paper boards with terra cotta cloth spine, with label on spine, by Constance Sayre.

(70)

225. F. SCOTT FITZGERALD'S PREFACE TO THIS SIDE OF PARADISE. Edited by John R. Hopkins with a drawing by John Thien based on a photograph of Fitzgerald, 1975. $12 \times 6 \%$; 15 unnumbered pages; 7-point Palatino. handset; title page in black and red; 150 copies on Rives Heavy; bound in brown cloth boards, paper label on front cover. A joint publication with Bruccoli Clark.

(71)

226. EW CORRECTIONS AND COMMENTS SP, corrections by Edmund Wilson of a text by Sherman Paul. 1976. $6 \times 9 \% ; 14$ unnumbered pages; 14-point Romanée, handset; black and red; 175 copies on Inveresk Cream; bound in gold and cream pastepaper boards with brown paper spine, printed on front, by Constance Sayre.

227. TALE OF THE CALIPH STORK, translated by Mark Twain, with illustrations by Eleanor Simmons, 1976. 9\% x 6\%; 31 unnumbered pages; 16-point Bembo, handset; black and terra cotta; 100 copies on Rives Heavy; bound in black cloth boards with illustrated label on front by Constance Sayre.

228. THE NAMES OF THE LOST, poems by Philip Levine, 1976. 111 $\times 6 \%$; pages; 16-point Romanée and 36-point Bembo Titling Capitals, handset; black. red, and transparent white; 200 copies on Fabriano Book; bound in black cloth boards, silkscreened on front with label on spine, by Constance Sayre.

(76)

229. PAGES FROM THE ILIAD, translated by Robert Fitzgerald with a preface by K. K. Merker, 1976. 11\% x 7\%; 12 unnumbered pages; 12-point and 18Romanée, handset; black and red; 175 copies on Inveresk Cream; bound handset; 300 copies on Ingre and Windhover, bound in gray paper wrappers. printed on front, by the Windhover Press.

\section{With Harry Duncan (The Cummington Press)}

400. HOMAGE TO BAUDELAIRE ON THE CENTENNIAL OF LES FLEURS $D U M A L$, from poets at the State University of Iowa, edited by Paul Engle. 1957. 11\% x 7\%; 26 pages; 16-point Romanée and 24-point Hadriano Stone Cut open capitals, handset; 475 copies on Shogun; bound in black paper covers. with label on front. Printed at the Typographic Laboratory in the State University of Iowa School of Journalism for the Cummington Press.

401. REQUIESCAT IN PACE PAUL WIGHTMAN WILLIAMS JR. MCMXXMCMLVI. Towards an Anniversary, an Elegy, by Barbara Gibbs with foreword by Allen Tate, 1957. With a silverpoint portrait by Ben Perlin; printed by collotype. $11 \times 7 \% ; 12$ unnumbered pages; 16-point Romanee, handset; 190 copies on Crown and Sceptre; bound in tan paper wrapper, with label on front. Collotype printed by E. Harold Hugo, Meriden Gravure Company. Printed for private distribution by Harry Duncan.

402. MY GLASS BROTHER, and Other Poems by Robert Patrick Dana, 1957. $10 \times 6 \%$; 11 pages; 16- and 18-point Centaur and Arrighi and 48-point Centaur Initials, handset; black and terra cotta; 50 copies on Alexandra Japan; bound in terra cotta paper wrapper, with label on front. (A project for the 
typography course Duncan taught at the State University of Iowa. The only item brought out under the imprint of the Constance Press.)

403. VALENTINES TO THE WIDE WORLD, Poems by Mona Van Duyn with illustrations by Fred Becker, 1958. $11 \times 8 \%$; 56 pages; 16-point Romanée and Lutetia Italic and 28-point Romanée Capitals, handset; black and red; 180 copies on Curtis Rag; bound in gray cloth boards, with label on spine, by Elizabeth Kner. A publication of the Cummington Press.

404. ERROR PURSUED, Poems by Helen Pinkerton, 1959. 7\% $\%$ 5\%; 22 unnumbered pages; 12-point Romanee and Lutetia Italic, handset; 190 numbered copies (I-XL on various imported papers, bound in Laga paper boards with brown leather spine, blocked in gold on spine; 41-190 on Crown and Sceptre, bound in light blue paper boards, blocked in gold on spine and front) with bindings by Elizabeth Kner. A joint publication of the Cummington Press and the Stone Wall Press.

405. GOLDEN CHILD, A Libretto by Paul Engle for an Opera composed by Philip Bezanson, with photographs from the telecast premiere on the Hallmark Hall of Fame, 1960. 93 x 6\%; 62 pages; 16- and 12-point Romanee and 28-point Romanee Capitals, handset; 105 numbered copies, signed by the librettist and composer, on Arches; bound in yellow, brown, and blackchecked cloth boards, with labels on spine and front, in black slip case, by Elizabeth Kner. Printed for Hallmark Cards, Kansas City, Missouri, who also brought out a large trade edition, printed offset.

406. JOURNEY TO A KNOWN PLACE, A Poem by Hayden Carruth, 1961. 10\% x 7\%; 31 pages; 16-point Romanée and 28-point Romanée Capitals, handset; four linoleum cuts by Harry Duncan, printed in brown, green, yellow, and red, respectively; 300 copies on Hayle; bound in gray-green paper boards with black cloth spine, blocked in gold on spine, by Russell-Rutter. Printed for New Directions, Norfolk, Connecticut.

\section{With A. D. Moore (The Finial Press)}

500. A LOCAL STORM, Poems by Donald Justice, 1963. 11\% x 7\%; 20 unnumbered pages; 14-point Spectrum, handset; black and red; 270 copies on Curtis Rag; bound in green paper covers, printed, and blindstamped with three rules, on front. A joint publication of the Stone Wall Press and the Finial Press.

(16)

501. TRAVERSEES, Poems in French by Paulene Aspel, with translations by Leigh DeNeef, Harry Duncan, Louis A. Haselmayer, Donald Justice, and the author, 1966. $11 \times 7 \% ; 46$ pages; 14-point Spectrum and Double Augustin Open Capitals, handset; ornaments by A. D. Moore in yellow-gold; 220 copies on Curtis Rag; bound in blue cloth boards, blocked in gold on spine (ornament on front), by Elizabeth Kner. A joint publication of the Stone Wall Press and the Finial Press.

502. MYSTERY OF BEAUTY, A Lecture by Soetsu Yanagi, 1966. $8 \times 5^{\frac{1}{4} ;} 11$ unnumbered pages; 12-point Romanée, handset; paragraph marks and title-page ornament cut by A. D. Moore; 350 copies on Shinsetsu; bound in green paper wrappers. Published by the Archie Bray Foundation, Helena, Montana. (27)

503. SILENT FLOWERS, A Collection of Japanese Haiku, edited by Dorothy Price and illustrated by Nanae Ito, 1967. $7 \frac{1}{1} \times 4 \frac{1}{2} ; 64$ unnumbered pages; 12-point Romanée, handset; black and red; large trade edition on Hallmark Eggshell Book; bound in black, pink, and terra cotta paper boards, printed on spine and front. Printed offset by the publisher, Hallmark Cards, Incorporated.

504. EXCELLENCY, A Sequence of Poems by John Pauker, with illustrations by Thomas Kovacs, 1967. $13 \times 10 ; 23$ unnumbered pages; 14-point Spectrum, handset; black, red, and gray; 230 copies on Rives Heavy; bound in red cloth boards, blocked in gold on front, with black silkscreen illustration on front, by Elizabeth Kner. Published by the Stone Wall Press. 